\title{
Descolamento da Epífise Proximal do Rádio Diagnosticado Tardiamente. Relato de Caso e Revisão da Literatura
}

\author{
Late Diagnosis of Proximal Radial Epiphysis Dislocation. Case Report and Literature Review
}

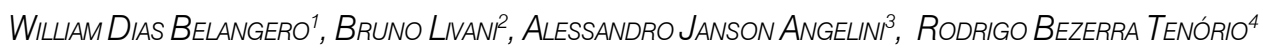

\section{RESUMO}

Os autores apresentam um caso de descolamento traumático da epífise proximal do rádio, diagnosticado 5 meses após luxação posterior do cotovelo, em uma criança com 9 anos de idade. Foi realizado redução e fixação da epífise avascular na metáfise proximal do rádio e, após 24 meses de seguimento, esta epífise encontravase revascularizada e o cotovelo apresentava flexão de $0-130^{\circ}$, pronação de $80^{\circ}$ e supinação de $30^{\circ}$.

\section{INTRODUÇÃO}

O descolamento traumático da epífise proximal do radio (DEPR) representa de $4,5 \%$ a $21 \%$ de todas as fraturas do cotovelo na criança. ${ }^{(1,3,5,6,8)}$ Landin e Danielsson (1986) relataram que as fraturas do cotovelo têm incidência média anual de 12/10.000 pacientes menores que 16 anos de idade, sendo que 14\% envolvem a região proximal do rádio(7). Estas lesões ocorrem em crianças entre $02 \mathrm{e}$ 16 anos de idade, com pico de incidência por volta dos 08 até os 11 anos de idade. ${ }^{(1,3,6,7,8,11,14,15)}$. Não há predomínio entre os sexos ${ }^{(7)}$, embora nas meninas a fratura ocorra mais precocemente. ${ }^{(15)}$

Anatomicamente, estas lesões envolvem a fise proximal do rádio, produzindo a fratura classificada como Salter-Harris tipo II e, menos freqüentemente, a Salter-Harris tipo I. Fraturas envolvendo a superfície articular da cabeça do rádio são raras nas crianças. $(6,11,14,15)$. O mecanismo de lesão mais comum é a queda com o punho em dorsiflexão, com o cotovelo estendido e o antebraço supinado, resultando na deformidade em valgo do cotovelo, com compressão da cabeça do rádio contra o capítulo umeral. $(1,3,4,9,12,13,14$,$) Lesões associadas, como a ruptura do ligamento$ colateral medial, com ou sem luxação posterior do cotovelo, ocorrem em 30 a 50\% dos casos. ${ }^{(1,3,8,10,14)}$ Quando ocorre o DEPR associado à luxação posterior do cotovelo, em geral a cabeça do rádio permanece anterior, enquanto que quando ocorre associado

\section{SUMMARY}

A case of traumatic dislocation of proximal radial epiphysis is reported, which was diagnosed 5 months after a posterior dislocation of the elbow in a 9 years old girl. Open reduction and fixation of the avascular epiphysis to the metaphysis was performed, and after 24 months follow-up the physis was vascularised and flexion ranged from $0-130^{\circ}$, pronation $80^{\circ}$ and supination $30^{\circ}$.

\section{INTRODUCTION}

Traumatic dislocation of proximal radial epiphysis (DPRE) represents 4.5 to $21 \%$ of all elbow fractures in children. ${ }^{(1,3,5,6,8)}$ Landin and Danielsson (1986) reported that elbow fractures have an annual average incidence of 12/10,000 patients under 16, and 14\% are related to the proximal radial region. ${ }^{(7)}$. These lesions use to occur in children between 2 and 16 years old, with peak incidence around the age of 8 to $11 .(1,3,6,7,8,11,14,15)$. There is not a gender predominance ${ }^{(7)}$, however in girls this lesion happens earlier. ${ }^{(15)}$

From an anatomical point of view, these lesions involve the proximal radial physis, producing lesions classified as Salter-Harris II and, less frequently, Salter-Harris I. Fractures involving articular face of radial head are rare in children. ${ }^{(6,11,14,15)}$. The most usual mechanism of lesion is a fall with the fist in dorsi-flexion, with stretched elbow and supinated forearm, resulting in a valgus deformity and compression of radial head against the humeral capitulus. (1,3,4,9,12,13,14,) Associated lesions, as colateral-medial ligament with or without posterior dislocation of the elbow joint occur in 30 to $50 \%$ of the cases. $(1,3,8,10,14)$ When DPRE occurs in association to posterior dislocation of the elbow joint, the radial head usually remains anterior, while, when linked to the reduction maneuver, posterior. ${ }^{(4,11,13)}$. The objective of this report is to report the results of the treatment of a late diagnosed traumatic dislocation of proximal radial epiphysis.
1 Prof. Assist. Dr. e Coordenador do Departamento de Ortopedia e Traumatologia FCM/UNICAMP

2 Pós-Graduando em Cirurgia e Médico Contratado do Grupo de Traumatologia 3 Pós-Graduando em Cirurgia e Médico Contratado do Grupo de Traumatologia 4 Médico Residente do 30. ano
1 Prof. Dr. Department Coordinator of DOT/HC/UNICAMP

2 Post-Graduate student and Orthopedic Surgeon of DOT/HC/UNICAMP

3 Post-Graduate student and Orthopedic Surgeon of DOT/HC/UNICAMP

4 Resident $3^{\text {rd }}$. year 
à manobra de redução da luxação, ela situa-se posteriormente. $(4,11,13)$. O objetivo deste relato é apresentar o resultado do tratamento do descolamento traumático da epífise proximal do rádio diagnosticada tardiamente.

\section{DESCRIÇÃO DO CASO}

Paciente com 9 anos de idade foi encaminhada ao Serviço de Ortopedia e Traumatologia, com perda da função do cotovelo esquerdo e dor há 5 meses. A história pregressa da moléstia relatada pelos pais referia que, após queda da própria altura, a criança tinha apresentado dor e edema no cotovelo direito. Foi atendida em outro Serviço por ortopedista que, após a realização de radiografias, fez o diagnóstico de contusão do cotovelo. O cotovelo da criança foi imobilizado com tala gessada por 8 dias e em seguida encaminhada à fisioterapia, sem melhora da função articular e da dor após 40 sessões.

Em nossa avaliação, feita após este período, a criança ainda queixava-se de dor intensa e continuava com o cotovelo esquerdo em atitude de flexão de 30 graus e movimento até 90 graus, pronação de $80^{\circ}$ e supinação de $0^{\circ}$ (Tabela 1). As radiografias iniciais, feitas após o acidente, mostravam o descolamento traumático da epífise proximal do rádio (Figura 1).

\section{CASE REPORT}

A 9 years old girl was reported to the Orthopedics and Traumatology Service with a 5 months history of stiffness and pain in the left elbow. Her parents reported that after a fall the child presented pain and swelling in the right elbow. Seen at an other orthopedic center, underwent radiographic examination and was diagnosed with an elbow contusion. Was submitted to immobilization of the elbow in a plaster splint for 8 days and in sequence sent to 40 sessions of physiotherapy without functional improvement.

Evaluated at our service after this period, the child still complained of severe pain and had the elbow in a 30 degree flexion position, allowing movement until 90 degree, pronation of 80 and supination of 0 degree (Table 1). Initial radiographic examination, performed after the accident, presented a traumatic displacement of the proximal radial epiphysis (Figure 1).

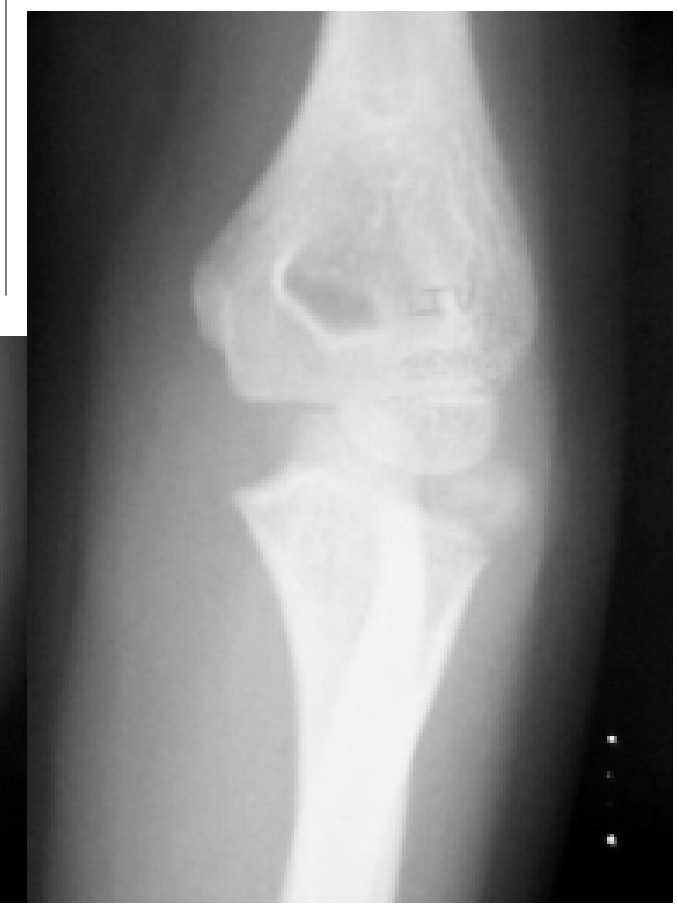

Figure 1:

Radiographic examination displaying traumatic displacement of proximal radial epiphysis

An open reduction was performed through a lateral Kocher approach, with a direct reach of the joint, which presented with abundant fibrous tissue. The proximal radial epiphysis was displaced and desvitalized. We opted for preserving it, performing a reduction and fixation through $1.5 \mathrm{~mm}$ Kirschner wires placed crossing the capitulus, due to great instability observed during the open reduction (Figure 2). An immobilization in a plaster cast was maintained during 6 weeks, when the Kirschner wires were removed, and the child sent to intensive physiotherapy treatment. 

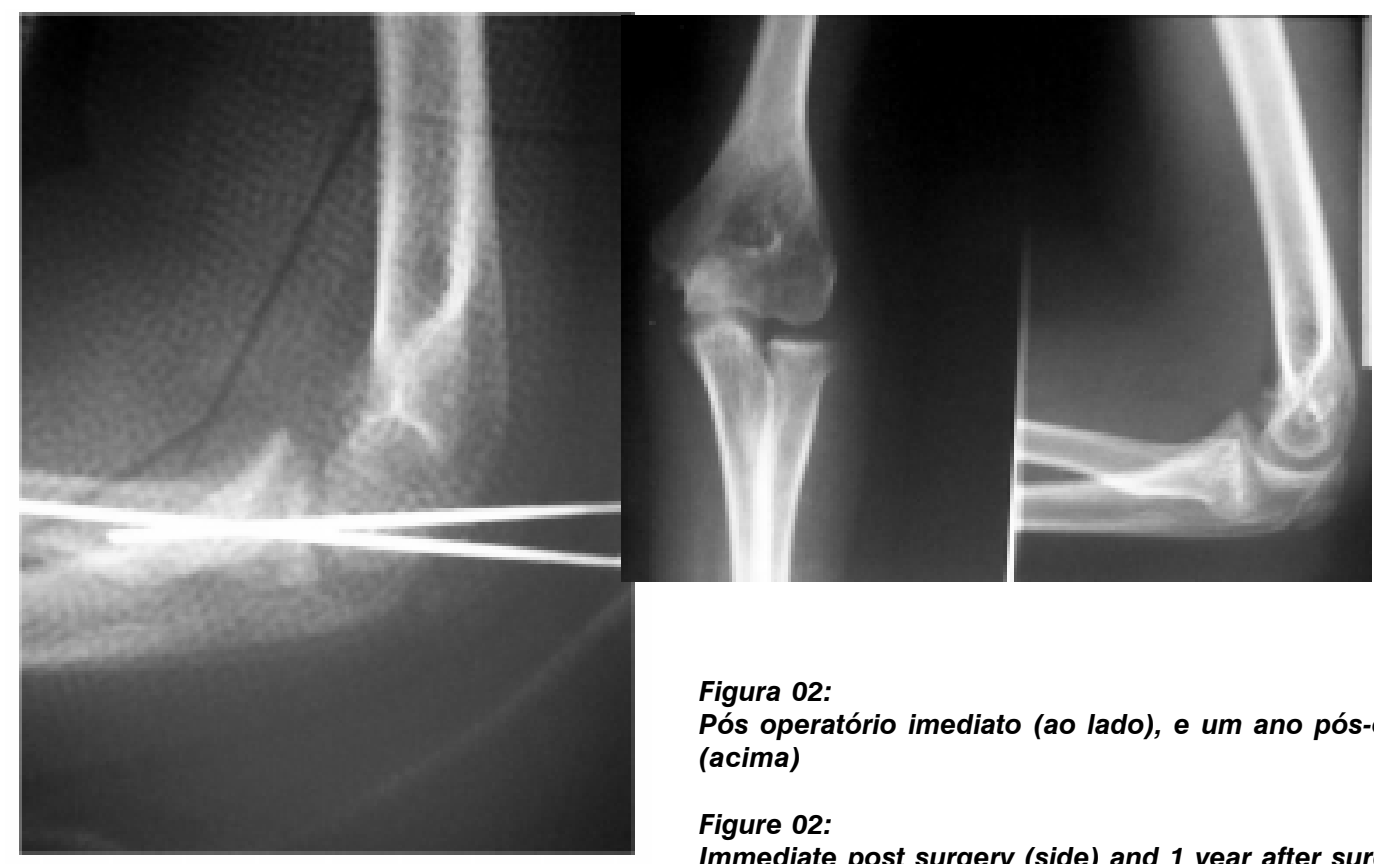

Figura 02:

Pós operatório imediato (ao lado), e um ano pós-operatório (acima)

Figure 02:

Immediate post surgery (side) and 1 year after surgical procedure (above).

No final do primeiro ano de seguimento pós-operatório foi realizada ressonância nuclear magnética (RNM) do cotovelo, que revelou revascularização da epífise proximal do rádio, com fechamento prematuro da placa de crescimento.(Figura 3)

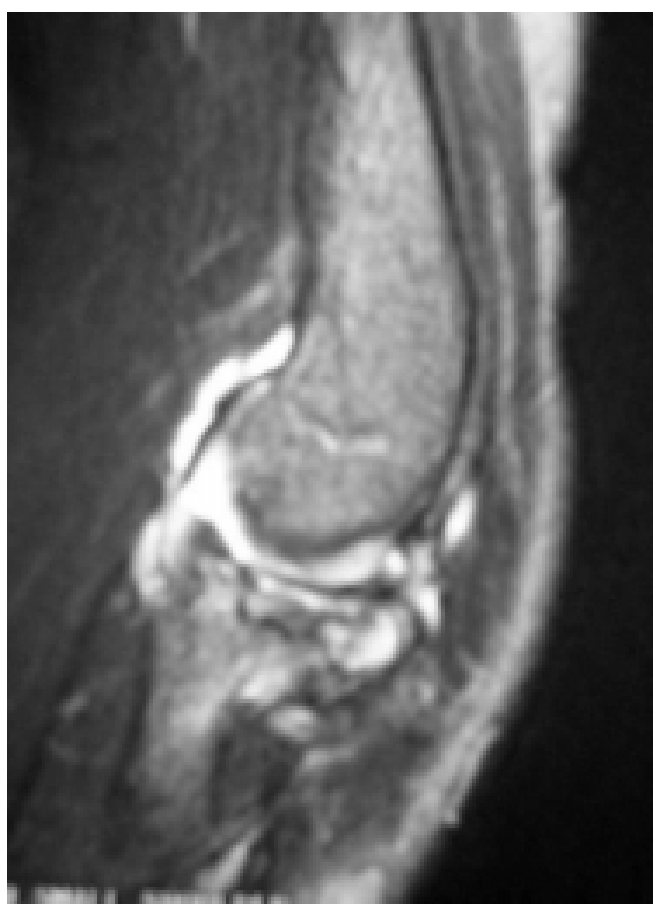

Atualmente, com 24 meses de pós-operatório, a criança encontra-se assintomática com flexo extensão do cotovelo de 0$130^{\circ}$, pronação de $80^{\circ}$, e supinação de $30^{\circ}$ (Figura 4).
At the end of the first year follow-up, a MRI examination of the elbow was performed, showing revascularization of the proximal radial epiphysis, with a premature closing of the growth plate. (Figure 3)

\section{Figura 03:}

RNM demonstrando revascularização da cabeça

\section{Figure 03:}

\section{MRI displays head revascularization}

Currently with 24 months follow-up, the child has no symptoms, with a flexo-extension movement range of 0-130 degree, pronation $80^{\circ}$ and supination $30^{\circ}$ (Figure 4). 
Tabela 1 - Avaliação da mobilidade articular do cotovelo direito no pré-operatório e pós-operatório tardio, comparado com o lado contralateral

Table 1 - Evaluation of movement range of right elbow joint pre-operative, late post-operative follow-up and comparative to left elbow.

\begin{tabular}{|c|c|c|c|c|c|c|}
\hline $\begin{array}{l}\text { Avaliaçáo Clinica } \\
\text { Clinical Evaluation }\end{array}$ & $\begin{array}{l}\text { Flexâo } \\
\text { (graus) } \\
\text { Floxion } \\
\text { (degree) }\end{array}$ & $\begin{array}{l}\text { Extensato } \\
\text { (graus) Exlension } \\
\text { (degreo) }\end{array}$ & $\begin{array}{l}\text { Pronaçlo } \\
\text { (graus) } \\
\text { Pronation } \\
\text { (degree) }\end{array}$ & $\begin{array}{l}\text { Supinaçấo } \\
\text { (graus) } \\
\text { Supination } \\
\text { (degree) }\end{array}$ & $\begin{array}{l}\text { Ang. } \\
\text { carregamento } \\
\text { Carrying angle }\end{array}$ & $\begin{array}{l}\text { Presença de dor } \\
\text { Pain }\end{array}$ \\
\hline $\begin{array}{l}\text { Pré-operatório } \\
\text { (passivo) } \\
\text { Pre-operative (passine) }\end{array}$ & 90 & 30 & 80 & 0 & 15 & $+++14+$ \\
\hline $\begin{array}{l}\text { Pós-operatório (ativo) } \\
\text { Post-operative (active) }\end{array}$ & 130 & 0 & 80 & 30 & 12 & - \\
\hline $\begin{array}{l}\text { Lado contra-lateral } \\
\text { Left elbow (comparathe) }\end{array}$ & 130 & 0 & 90 & 90 & 12 & - \\
\hline
\end{tabular}

\section{DISCUSSÃO}

O diagnóstico radiológico de DEPR, assim como o diagnóstico das demais lesões do cotovelo na criança, são difíceis, podendo, inclusive, passar desapercebidos devido à ausência de ossificação ou ossificação incompleta das epífises. De maneira geral, estas lesões podem ser diagnosticadas com segurança por radiografias simples à partir do terceiro ano de vida, quando o núcleo da epífise proximal do rádio inicia a sua ossificação. Nas situações de dúvida é sempre recomendado que se faça uma radiografia do lado normal para ser comparada com o lado afetado. No entanto, mesmo quando diagnosticadas adequadamente, estas lesões que envolvem a epífise proximal do rádio podem evoluir com alta incidência de complicações (20 à 50\%), tais como a perda do movimento articular, a necrose avascular, o fechamento prematuro da placa de crescimento, a ossificação peri-articular, a pseudoartrose, a consolidação viciosa, a sinostose rádio-ulnar proximal e o cubito valgus. ${ }^{(1,3,4,7,10,11,14,15)} \mathrm{O}$ aparecimento ou não destas complicações dependem da intensidade do trauma inicial, da presença ou não de lesão da placa de crescimento e, principalmente, do tipo de tratamento realizado ${ }^{(8,11,15)}$ Dependendo do grau do desvio e da idade do paciente, a tendência atual é realizar o tratamento incruento, já que este oferece os melhores resultados. Nas crianças menores do que 5 anos o desvio aceitável pode chegar a $50^{\circ}$, entre 5-10 anos não deve ultrapassar $30^{\circ}$ e em meninas maiores de 12 anos e meninos maiores de 14 anos não deve exceder $15^{\circ}(4)$. No caso em questão, o desvio não era passível de ser mensurado, já que a epífise encontrava-se ao lado da metáfise proximal do rádio e sem ligação anatômica com a mesma. Nestas circunstâncias, a dúvida que poderia existir era a de se preservar ou não a epífise que encontrava-se avascular. Apesar disso, optouse pela manutenção da mesma, já que os resultados apontados pela literatura são uniformemente ruins quando se realiza sua retirada, com mais de $50 \%$ de chance de desenvolver sinostose rádio-ulnar proximal, deformidade em valgo progressiva do cotovelo e luxação rádio-ulnar distal (2). O resultado obtido não só valida a conduta, como também demonstra que este procedimento é perfeitamente

\section{DISCUSSION}

Radiological diagnosis of DPRE, as well as other elbow lesions in children are difficult, and can also be misdiagnosed due to the absence of ossification or incomplete ossification of the epiphysis. In general, these lesions can more safely be diagnosed starting from the third year of age, when the proximal radial epiphysis nucleus starts its ossification. When there is doubt, it is always recommended to compare to a radiographic exam of the opposite side. However, even when appropriately diagnosed, these lesions involving the proximal radial epiphysis can lead to a high incidence of complications (20 to 50\%) as stiffness, avascular necrosis, premature closing of the growing plate, peri-articular ossification, pseutoarthrosis, malunion, radio-ulnar synostosis and cubito valgus. ${ }^{(1,3,4,7,10,11,14,15)}$ Whether or not these complications will occur, is dependent on the intensity of the initial trauma, if the growing plate was or not injuried and, mainly, the kind of treatment performed. ${ }^{(8,11,15)}$ According to the degree of deviation, and age of the patient, the current trend is to a closed treatment since it allows better results. In children under 5 years old, the accepted deviation can reach $50^{\circ}$, between 5 and 10 years old, should not be above $30^{\circ}$ and in girls above 12 years old, and boys above 14, should not exceed 150. (4). In this case, the deviation was not possible to evaluate, since the epiphysis was by the side of the proximal radial metaphysis, without any anatomical link to it. In these circumstances, the reasonable doubt would be to preserve or not the avascular epiphysis. However, it was decided to keep it, since in the literature the results are consistently bad when it is decided to remove it, with more than $50 \%$ chance of development of a proximal radio-ulnar synostosis, progressive valgus deformity of the elbow, and distal radio-ulnar dislocation (2). The result that was obtained, not only validates the decision, as well as demonstrates that this procedure is justifiable, since, even avascular, the epiphysis had an important function as a biological spacer while not revascularized and incorporated to the radial proximal metaphysis. It is however necessary to keep this child under follow-up in order to detect any possible abnormality which can happen due to the absence of growth at the proximal growth plate, which, despite contributing to 
justificável, pois mesmo avascular a epífise teve função importante de espaçador biológico até ser revascularizada e incorporada na metáfise proximal do rádio. A criança, no entanto, deverá continuar sendo mantida em seguimento clínico para se detectar possíveis anormalidades decorrentes da ausência de crescimento da placa proximal do rádio, que apesar de contribuir menos intensamente que a distal, responde por até $25 \%$ do crescimento total do rádio.

\section{CONCLUSÃO}

Apesar da epífise proximal do rádio estar completamente separada da metáfise por 5 meses, a sua redução permitiu que a mesma pudesse ser revascularizada e incorporada à metáfise proximal do rádio e conseqüentemente, a recuperação funcional do cotovelo

\section{REFERÊNCIAS}

1. Bernstein SM, McKeever P, Bernstein L: Percutaneous reduction of idsplaced radial neck fractures in children. J. Pediatr Orthop 13:8588,1993

2. Bohrer, JV: Fractures of the Head and Neck of the Radius. Ann Surg., 97: 204-208, 1933.

3. D'Souza S, Vaishya r, Klenerman L: Management of radial neck fractures in children: A retrospective analysis of one hundred patients. J Pediatr Orthop 13:232-238,1993.

4. Fowles JV, Kassab M T: Observations concerning radial neck fractures in children. J Pediatr Orthop 6: 51-57, 1986.

5. Gaston SR, Smith FM, Baab O: Epiphyseal injuries of the radial head and neck. Am J Surg 85:266-276, 1953.

6. Kaufman B, Rinott MG, Tanzman M: Closed reduction of fractures of the proximal radius in children. J Bone Joint Surg 71 B:66-67, 1989.

7. Landin LA, Danielsson LG: Elbow fractures in children. Na epidemiologic analysis of 589 cases. Acta Orthop Scand 57:309-312,1986.

8. Metaizeau JP, Lascombes P, Lemelle JL, Finlayson D, Prevot J: Reduction and fixation of displaced radial neck fractures by closed intramedullary pinning. J Pediatr Orthop 13:355-360, 1993.

9. Peters CL, Scott Sm: Compartment syndrome in the forearm following fractures of the radial head or neck in children. J Bone Joint Surg 77 A:1070-1074,1995.

10. Reidy JA, Van Gorder GW: Treatment of displacement of the proximal radial epiphysis. J Bone Joint Surg 45 A: 1355-1358,1963.

11. Rodríguez-Merchán EC: Displaced fractures of the head and neck of the radius in children: Open surgery and temporary transarticular internal fixation. Orthopedics 14:697-700,1991.

12. Rodrígues-Merchán EC: Percutaneous reduction of displaced radial neck fractures in children. J Trauma 37:812-814,1994.

13. Sponseller PD: Problem elbow fractures in children. Hand Clin 10:495505, 1994.

14. Steele JA, Graham HK: Angulated radial neck fractures in children. A prospective study of percutaneous reduction. J Bone Join Surg 74 B:760-764, 1992.

15. Steinberg EL, Golomb D, Salama R, Weintroub S: Radial head and neck fractures in children. J Pediatr Orthop 8:35-40,1988. the growth at a lesser extent than the distal one, is responsible for up to $25 \%$ of the radial growth.

\section{CONCLUSION}

Even though the proximal radial epiphysis was completely separated of the radius for a period of 5 months, its reduction allowed its revascularization, and incorporation into the proximal metaphysis, and consequently, allowed the elbow to be functionally recovered. 